\title{
ANALITIČKI PRISTUP IZBORU LOKACIJA SISTEMA VIDEO-NADZORA I ANPR SISTEMA U URBANIM PODRUČJIMA
}

\author{
Milan Gligorijević ${ }^{1}$, Siniša Milković ${ }^{2}$ \\ UDK=004.9:621.397(1-21) \\ Aleksandar Maksimovic ${ }^{3}$ \\ https://doi.org/10.18485/fb_ubur.2018.1.ch18 \\ ${ }^{1}$ Kriminalističko-policijski univerzitet, Beograd, \\ milan.gligorijevic@mup.gov.rs \\ ${ }^{2}$ MUP R Srbije, Beograd, \\ sinisa.milkovic@mup.gov.rs \\ ${ }^{3}$ MUP R Srbije, Centar za reagovanje na napade na informacioni sistem MUP-a \\ (CERT), Beograd, aleksandar.maksimovic@mup.gov.rs
}

\section{Sažetak}

Informaciono-komunikacione tehnologije i sistemi današnjice predstavljaju neizostavan segment društvenog života. Bez njih savremeni čovek gotovo da ne bi mogao ni da komunicira sa zajednicom, što bi kao posledicu moglo da dovede u pitanje i njegov opstanak zbog nemogućnosti adekvatnog odgovora na mnoge izazove sve surovijeg i dinamičnijeg okruženja. U takvim okolnostima upotreba informaciono-komunikacionih sistema i tehnologija je od krucijalnog značaja.

Razvoj visokih tehnologija je doneo revolucionarne promene u svim oblastima društvenog života. Skoro da nema oblasti u kojoj nisu našle svoju primenu - počev od tehnike, preko privrednih i industrijskih procesa, u okviru administrativnih aparata, nauke, obrazovanja, medicine do oblasti nacionalne odbrane i bezbednosti. Ključnu primenu visokih tehnologija u sferi bezbednosti predstavlja, između ostalog, mogućnost njihove upotrebe kao mehanizama bezbednosne zaštite - samostalno ili kao podrška drugim vidovima zaštite. Jedna od tih mogućnosti su upravo sistemi video nadzora koji predstavljaju najsavremeniji model uvida i kontrole nad određenim bezbednosnim pojavama i događajima i što je posebno važno naglasiti - daju mogućnost pravovremene reakcije na određene vidove ugrožavanja fizičke i imovinske bezbednosti građana. Istovremeno, predstavljaju dobar način za sticanje iskustava od značaja za planiranje bezbednosnih mera povodom, budućih, konkretnih bezbednosnih događaja i pojava. Ako tome dodamo i činjenicu da sistemi video-nadzora imaju velik preventivni potencijal, onda je jasno da se svrstavaju u red pouzdanijih savremenih sredstava bezbednosne zaštite.

Primeri takvih sistema su mnogobrojni, a u ovom radu se obrađuje poslednja generacija sistema video-nadzora, takozvani ,,inteligentni video-nadzor“, sa posebnim osvrtom na pravilan pristup, analitički aspekt i metodologiju planiranja, izbora lokacija i izgradnje ovih sistema u urbanim područjima. Takođe, u radu ukazujemo i na veoma važnu ulogu i značaj upotrebe inteligentnih sistema video nadzora u svakodnevnom životu i radu ljudi u urbanim sredinama. 
Sa aspekta pružanja kvalitetne bezbednosne zaštite građanima, njihovoj i imovini uopšte, urbana područja su veoma zahtevna i kompleksna. Primena sistema video-nadzora, uključujući i naprednu video analitiku snimljenog materijala, kao jedna od komponenti savremene urbane bezbednosti pretpostavlja, pre svega, pravilan izbor lokacija, za šta prvi i osnovni uslov predstavlja primena određenih kvalitativnih/analitičkih, statističkih i geoprostornih metoda.

U radu se obrađuju ove metode i daje pregled njihovih mogućnosti u tom pogledu. Analitička/kvalitativna metoda se obrađuje iz ugla korišćenja raspoloživih bezbednosnih informacija koje ukazuju na urbane ,žarišne“ tačke, kao i iz ugla načina njihovog prikupljanja i obrade, ali i potrebe iznalaženja modela daljeg prikupljanja i klasifikacije, uz naglasak na konstantno praćenje i analizu, kako bi se obezbedila dobra osnova za eventualno revidiranje izabranih lokacija u skladu sa tokovima i razvojem stanja bezbednosti. Skreće se pažnja na jednu od veoma značajnih analitičkih metoda, a to je neposredan razgovor sa operativnim radnicima policije kako bi se tim putem dobila kvalitetna saznanja i iskustva neophodna za procenu izbora lokacije, a koja se ne mogu dobiti drugim putem.

Ukazuje se na mogućnosti statističkih metoda, uz pomoć kojih je potrebno izdvojiti i ukrstiti najrazličitije podatke - počev od stepena prisustva građana, saobraćaja i putničkih vozila, do vrste, obima i učestalosti bezbednosnih pojava i događaja, a naročito težih krivičnih dela i prekršaja i saobraćajnih nezgoda i njihovih posledica na određenim gradskim područjima itd.

Korišćenje savremenih informatičkih alata u izboru lokacija karakteriše i upotreba geografskog informacionog sistema kao svojevrsnog metoda za analizu geoprostornih podataka od izuzetnog taktičkog i strateškog bezbednosnog značaja čemu se u radu, takođe, posvećuje pažnja. Geografska informacija sa aspekta analize stanja i kretanja kriminala omogućava da sagledamo sve uslove koji u tom smislu vladaju na konkretnom mestu i pomaže da uočimo razlike između takvih sličnih pozicija. GIS treba da nam odgovori na pitanja: gde se nalazi lokacija, koji su uticaji šireg okruženja ili uticaji koji mogu dovesti do promena na toj lokaciji i koje su najbrže, najkraće ili najpreče putanje. Geografski informacioni sistem (GIS) jedan je od najmoćnijih alata za upravljanje prostornim podacima koji na najbolji način pomaže da se razume priroda prostora. Pruža velike mogućnosti, koje još nisu u dovoljnoj meri iskorišćene niti su u potrebnoj meri uvedene u praksu i rad policije.

Uporedo sa GIS-om, rad ukazuje na potrebu mapiranja krivičnih dela, prekršaja, saobraćajnih nezgoda pa i požara i eksplozija i drugih oblika ugrožavanja bezbednosti naročito onih kojima se dovode u opasnost lokacije sa velikom koncentracijom ljudi (frekventna mesta, uobičajena okupljališta, javni skupovi, poslovni događaji, turističke, kulturne i verske manifestacije itd). Mapiranje predstavlja značajan izvor podataka i kvalitetan način predstavljanja podataka za procenu lokacija za izgradnju sistema video-nadzora.

U radu se predstavljaju određeni problemi koji mogu uticati na kvalitet u primeni analitičke, statističke i geoprostornih metoda za izbor lokacija koji se odnose na nepotpunost informacija i podataka, nedovoljnu òbučenost, inkompatibilnost neophodnih programskih sistema, tehničke ograničenosti upotrebe podataka i druge nedostatke.

Takođe, pominje se značaj inteligentnog sistema video-nadzora sa aspekta mogućnosti rasvetljavanja konkretnih krivičnih dela, što se u policijskoj praksi do sada nebrojano puta pokazalo, kao i razjašnjenja drugih bezbednosnih događaja. Njihovu upotrebnu vrednost čini daleko veća i kvalitetnija mogućnost prikupljanja informacija o novim pojavnim oblici- 
ma ugrožavanja bezbednosti i načinima na koji se odvijaju, kao i prikupljanja informacija koje u perspektivi mogu biti od koristi za primenu i razvoj prediktivno-analitičke metode, odnosno prognoze razvoja određenih bezbednosnih opasnosti i rizika na konkretnim lokacijama.

Poseban akcenat je stavljen na video-analitiku, kao alat koji predstavlja integralni deo inteligentnih sistema video-nadzora. Omogućava analizu video-materijala po više različitih osnova, kao što su: analiza ponašanja u zoni nadzora kamere (detektovanje događaja u realnom vremenu, kao što su ostavljanje/pomeranje ili napuštanje nekog objekta, povećan broj ljudi na nekom prostoru, ulazak u definisanu zonu, zadržavanje u definisanoj zoni, uočavanje pogrešnog smera kretanja, brojnost prisustva osoba i slično); inteligentna pretraga video-materijala prema različitim zadatim kriterijumima: prostoru, vremenu, dešavanju na sceni, objektu i tipu objekta (vozilo, čovek, predmet), boji objekta, zoni na sceni, smeru kretanja itd; video-sinopsis, kao sažet prikaz video-materijala detektovanjem definisanih promena scene; prepoznavanje registarskih tablica motornih vozila u realnom vremenu i pretragom snimljenog materijala; automatsko prepoznavanje lica; i utvrđivanje trajektorija lica i vozila kroz integraciju sa GIS-platformom; itd.

Ključne reči: informaciono-komunikacione tehnologije, video-nadzor, analitika, video-analitika, metod, lokacija inteligentni sistem video-nadzora

\section{Opšte karakteristike i dosadašnja iskustva u primeni video-nadzora}

Jedan od kriterijuma savremenog razvoja jeste nivo i brzina razvoja telekomunikacionih tehnologija. Telekomunikacije čine veoma širok spektar oblasti koje nalaze primenu u svakodnevnom životu ljudi, a jedna od njih je oblast video-nadzora, koji se primenjuje u različitim delatnostima čovekovog rada, kao što su medicina, poljoprivreda, zaštita čovekove okoline, industrijska proizvodnja, bezbednost itd.

Do sada najveću primenu, više decenija unazad, video-nadzor nalazi u oblasti bezbednosti u funkciji praćenja bezbednosnih događaja i pojava. Praćenje određenog prostora sa više uređaja za video-nadzor, odnosno kamera, na jednom ili više mesta, pri čemu sámo mesto praćenja može biti udaljeno, zatim mali broj angažovanog ljudstva i stalno praćenje, uz mogućnost bržeg i kvalitetnijeg donošenja odluka, svakako da predstavljaju razloge za njegovu najširu primenu.

Danas je podrška video-nadzora od izuzetnog značaja u mnogim slučajevima ugrožavanja bezbednosti građana i imovine, uključujući i vanredne situacije. Obezbeđenja objekata, saobraćaja i državne granice predstavljaju standarde koji su regulisani zakonskim propisima. Vidna je ekspanzija bezbednosnih oblasti i delatnosti u kojima se koristi video-nadzor. Sve to ukazuje na neophodnost kvalitetnog i planski uređenog sistema video-nadzora koji sve više dolazi do izražaja u viziji 
mnogih sfera savremenog života, među kojima je i vizija savremenog urbanog razvoja, koja se ogleda u tzv. pametnim gradovima (u sprezi sa ostalim tehnologijama, $\mathrm{LTE}^{1}$ itd).

I u našoj zemlji je poslednjih godina sve rasprostranjeniji video-nadzor, a prve kamere koje registruju saobraćajne prekršaje uvedene su 2011. godine. Dosadašnja iskustva u korišćenju video-nadzora u oblasti bezbednosti saobraćaja ukazuje na opravdanost upotrebe ovakvog sistema u pogledu smanjenja saobraćajnih nezgoda i otkrivanja prekršaja u toj oblasti. Kao primer može se uzeti teritorija Grada Beograda, odnosno područje opština sa najvećim protokom saobraćaja i ujedno najvećim brojem kamera - Novi Beograd i Stari Grad. Naime, broj saobraćajnih nezgoda je u periodu korišćenja video-nadzora - od 2011. do 2016. godine - daleko manji u odnosu na period kada video-nadzora nije bilo - od 2003. do 2008. godine - i to za $22 \%$ u opštini Novi Beograd i čak $40 \%$ u opštini Novi Beograd. Takođe, manji je i broj poginulih lica (opao je sa 85 u periodu od 2003. do 2008. godine na 43 u periodu od 2011. do 2016. godine na području opštine Novi Beograd i sa 18 na 13 na području opštine Stari Grad).

Svakako da je smanjenju broja saobraćajnih nezgoda doprinelo više činilaca, među kojima je i sistem video-nadzora, što, uostalom, potvrđuje veliki broj prekršaja otkrivenih pomoću video-nadzora. Naime, na teritoriji grada Beograda u periodu od 2011. do 2016. godine evidentirano je čak 214.940 prekršaja u vezi sa vožnjom žutom trakom, ili 35.823 u proseku godišnje. Podaci pokazuju da je njihov broj varijabilan iz godine u godinu, ali da je u smanjenju za skoro $16 \%$ u 2016. u odnosu na 2011. godinu. Takođe, zabeležena su i 5.642 prekršaja u vezi s prolaskom na crveno svetlo semafora ili 940 u godišnjem proseku. NJihov broj je u smanjenju od 2011. do 2014. godine. U 2014. godini dolazi do naglog povećanja, a zatim do ponovog smanjenja. U 2016. godini je broj tih prekršaja manji za 4,7 puta u odnosu na 2011. godinu.

Kada je reč o prekršajima u vezi s neprilagođenom brzinom kretanja, prema raspoloživim podacima, u periodu od 2013. do 2015. godine video-nadzorom je zabeleženo 40.150, ili 10.037 u proseku godišnje. Njihov broj je u padu od 2013. do 2015. U 2016. dolazi do povećanja njihvog broja u odnosu na 2015. godinu. U celini, broj ovih prekršaja je u smanjenju za $11 \%$ u 2016. u odnosu na 2013.

1 LTE (engl. Long-term evolution) jeste svetski standard za veoma brze bežične telekomunikacione tehnologije, poznatiji kao $4 \mathrm{G}$ - četvrta generacija mobilnih telekomunikacionih tehnologija. 
Grafikon 1: Kretanje žutom trakom - broj prekršaja otkrivenih video-nadzorom na teritoriji Grada Beograda

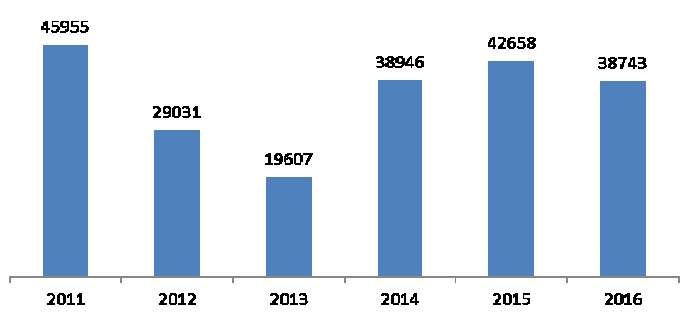

Grafikon 2: Prolazak na crveno svetlo semafora - broj prekršaja otkrivenih video-nadzorom na teritoriji Grada Beograda

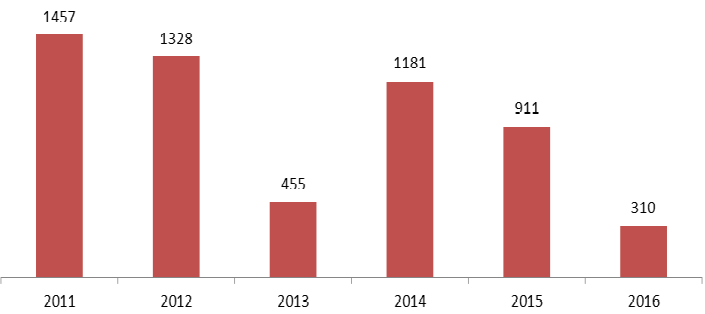

Grafikon 3: Neprilagođena brzina kretanja - broj prekšaja otkrivenih video-nadzorom na teritoriji Grada Beograda

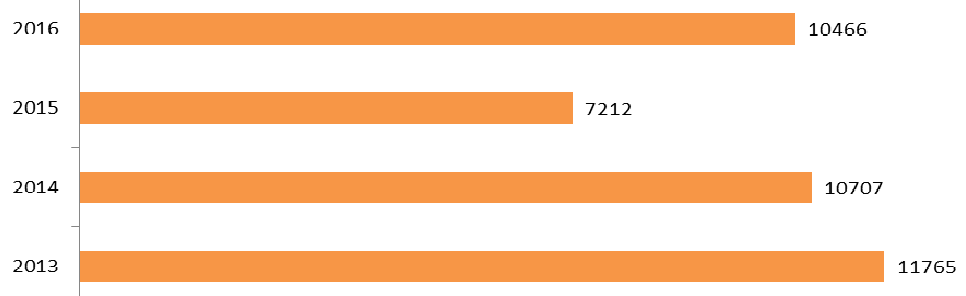




\section{Razvoj sistema video-nadzora i prikaz alatâ savremenih video-nadzora}

Prvi sistemi video-nadzora bili su analognog tipa. Opšti razvoj elektronskih tehnologija doveo je do prelaska sa analognih na digitalne sisteme video-nadzora. Današnji sistemi su prešli dug put od ranih analognih kamera povezanih putem video-rekordera, mrežnih kamera i PC servera za arhiviranje do potpuno digitalnih sistema. Međutim, od potpuno analognog do potpuno digitalnog sistema postoji nekoliko rešenja koja spadaju u red delimično digitalnih. tj. predstavljaju kombinaciju analogne i digitalne tehnologije. Poseduju određen broj digitalnih komponenti, ali ipak zadržavaju analogni prenos, u okviru kojeg se vrši analogno-digitalna i digitalno-analogna konverzija video-signala.

U pravim digitalnim sistemima video-slike zadržavaju digitalni oblik na putu od kamere kroz kablovski sistem preko $\mathrm{IP}^{1}$ mreže do video-servera i monitoring-centra. Njihove osnovne karakteristike su skalabilnost i fleksibilnost. Rešenja bazirana na otvorenim IP standardima omogućavaju nadzor i snimanje gde god da se korisnik nalazi, a mrežna kamera, ili IP kamera, može se opisati kao kamera i računar objedinjen u jedan inteligentan uređaj. Mrežna kamera šalje video-snimak u realnom vremenu direktno preko IP mreže, kao što su LAN, ${ }^{2}$ intranet i internet, a korisnicima omogućava gledanje videa i/ili upravljanje kamerom korišćenjem standardnog Web browser-a ili specijalizovanog softvera za upravljanjem videom sa bilo kojeg računara (lokalnog ili udaljenog) u mreži.

Većina sistema video-nadzora se još uvek bazira na klasičnoj analognoj tehnologiji, ali se sve više korisnika odlučuje na korišćenje napredne IP tehnologije. Takav trend je izražen zbog brojnih prednosti koje koje pruža IP tehnologija: megapikselna rezolucija, daljinski pristup, prenos videa u realnom vremenu i prenos signala bez smetnji.

Razvojem izuzetno kvalitetnih digitalnih kamera $\mathrm{HDM}^{3}$ i $4 \mathrm{~K}^{4}$ rezolucije dobija se novi kvalitet u sistemima video-nadzora, koji omogućava napredne alate tzv. video-analitike i koji će, kao takav, nalaziti sve veću primenu u različitim oblastima bezbednosti. U nastavku sledi kratak prikaz alata video-analitike.

Analiza kretanja i ponašanja u zoni nadzora kamere predstavlja važan video-analitički alat, koji ima širok dijapazon mogućnosti. Praćenje određenog prostora sa analizom svih zadatih „,nepravilnosti“ u realnom vremenu daje prednost bezbednosnim službama, jer omogućava trenutno reagovanje i odgovor na događaj.

1 IP (engl. Internet protocol address) jeste jedinstveni broj sličan telefonskom, koji koriste mašine (najčešće računari) u međusobnom saobraćaju putem interneta.

2 LAN (engl. Local Area Network - Lokalna računarska mreža) sačinjava skup računara koji su povezani u jednu računarsku mrežu, na relativno malom prostoru, kao što su kancelarija, više kancelarija ili zgrada.

3 HDM (eng. High-Definition Multimedia) jeste oznaka za multimedijalne uređaje, najčešće digitalne kamere, visoke rezolucije.

$44 \mathrm{~K}$ je standard za uređaje i sadržaje koji imaju horizontalnu rezoluciju veću od 4.000 piksela. 
Detektovanje događaja u realnom vremenu, kao što su ostavljanje nekog predmeta ili njegovo pomeranje, brojčani podaci o prisustvu i detekcija povećanog broja osoba na nekom prostoru, neplaniran ulazak i zadržavanje u definisanoj zoni, uočavanje ,pogrešnog“ smera kretanja, još su neke od mogućnosti ovog alata.

Inteligentna pretraga video-materijala prema različitim zadatim kriterijumima kako u realnom vremenu tako i na snimljenom materijalu, takođe, predstavlja novinu od značaja za rad službi bezbednosti i policije. Radi se o mogućnosti pretrage video-materijala radi pronalaska određenog lica, vozila ili predmeta, i to $\mathrm{u}$ realnom vremenu i prema zadatom periodu i prostoru (jedan ili više prostora), dešavanju na sceni, objektu i tipu objekta (vozilo, čovek, predmet), boji objekta, zoni na sceni, smeru kretanja itd.

Video-sinopsis, ili sažet prikaz video-materijala, detektovanjem definisanih promena scene, skraćuje vreme video-analize i doprinosi bržem donošenju odluka.

Prepoznavanje registarskih tablica motornih vozila u realnom vremenu i pretraga snimljenog materijala spada u red poznatih i najzastupljenijih alata videoanalitike korišćenih do sada. Tačno prepoznavanje izvršenih saobraćajnih prekršaja i automatska priprema naloga za naplatu predstavlja funkciju ovog alata, koja je dobijena na osnovu povezivanja sa informacionim sistemom. Korišćenje ovog alata u sistemu video-nadzora u našoj zemlji doživljava ekspanziju u brojnim gradovima (finansira se novcem iz budžetskih prihoda po osnovu procesuiranih saobraćajnih prekršaja). Video-analitički alat dozvoljava i opciju praćenja saobraćaja, potrage za konkretnim vozilom, snimanja na više lokacija i rekonstrukcije kretanja vozila izradom trajektorije.

Automatsko prepoznavanje lica je alat koji se pojavio u skorije vreme. Svi proizvođači njegovog softvera uglavnom su u fazi testiranja. Radi se o kompleksnom alatu, uslovljenom kvalitetom snimka koji se obrađuje. Mogućnost njegove primene je ogromna.

Još jedan alat je važno pomenuti. Reč je o utvrđivanju trajektorije lica i vozila kroz integraciju sa GIS ${ }^{1}$ platformom. Definisanjem trajektorije kretanja i povezivanjem sa GIS-platformom moguće je u kratkom vremenskom periodu izvršiti rekonstrukciju vremena i putanje kretanja.

Očigledno je da napredna IP tehnologija i razvoj izuzetno kvalitetnih digitalnih kamera pružaju velike mogućnosti od značaja za oblast bezbednosti. Temelj za praktičnu primenu ovih ,pametnih“ sistema video-nadzora i njihov što potpuniji učinak čini pravilan izbor lokacija za postavljanje uređaja video-nadzora. Za tako nešto je potreban stručan, analitički pristup, zasnovan na informacijama dobijenim kombinacijom više metoda.

1 GIS (skr. od geografski informacioni sistem) označava sistem za upravljanje prostornim podacima, odnosno računarski sistem sposoban za integrisanje, skladištenje, uređivanje, analizu i prikaz geografskih informacija. 


\section{Metode za izbor lokacija video-nadzora}

Statistički metod je metod dobijanja prvih informacija o lokacijama za postavljanje video-nadzora u urbanim područjima, koji se odvija u više faza. U prvoj fazi se prikupljaju statistički pokazatelji koji se odnose na obim, vrstu i strukturu bezbednosnih događaja, odnosno krivičnih dela, prekršaja, saobraćajnih nezgoda, požara i eksplozija, na kompletnom urbanom prostoru koje je predmet interesovanja. U sledećoj fazi se vrši izbor užih gradskih zona, prvenstveno sa najvažnijim bezbednosnim događajima i onih sa najtežim posledicama - krivična dela sa velikom materijalnom štetom, krivična dela sa elementom nasilja, a naročito sa smrtnim posledicama i teškim telesnim povredama, teži prekršaji protiv javnog reda i mira, saobraćajne nezgode sa nastradalim licima, požari i eksplozije sa smrtnom posledicom i velikom materijalnom štetom itd.

Nakon toga sledi proces identifikovanja još užih lokacija na kojima je došlo do ovih bezbednosnih događaja, pri čemu se mogu vršiti statistička (pre)grupisanja po različitim kriterijumima, kao što su to lokacije na kojima se konstantno pojavljuje veći broj istih bezbednosnih događaja; lokacije sa većim brojem različitih bezbednosnih događaja; lokacije sa najtežim posledicama bezbednosnih događaja itd. U okviru toga se statistička istraživanja mogu kretati u pravcu identifikacije određenih bezbednosnih karakteristika, ukrštanjem podataka o najužem mestu događaja sa vremenom događaja, načinom izvršenja, korišćenom sredstvu, predmetom oduzimanja itd.

Treba imati u vidu da statistički metod ne daje potpunu sliku neophodnu za donošenje odluke o postavljenju video-nadzora. Razloga za to ima nekoliko. Primena statističke metode može biti opterećena brojnim problemima, kao što su nedostatak potrebnih ili nepotpunost sadašnjih statističkih evidencija, greške prilikom njihovog registrovanja u statističkim bazama podataka, neblagovremene izmene u bazama podataka potrebne za statističko evidentiranje novonastalih bezbednosnih događaja, nedostatak ili nepotpunost brojčanih podataka o unutrašnjim elementima bezbednosnih događaja, kao što su to, primera radi, vreme, mesto ili predmet izvršenja nekog od najtežih krivičnih dela itd.

Pored toga, statistička metoda ukazuje samo na otkrivene bezbednosne događaje, pa samim tim ne daje celovitu sliku bezbednosnih problema na konkretnoj lokaciji. Svi ovi problemi vode u opasnost od pogrešnog zaključivanja. Iz tih razloga neophodan je kvalitativni pristup, koji naročito dolazi do izražaja u situacijama kada se na više lokacija pojavljuje isti ili sličan broj bezbednosno interesantnih događaja.

Kvalitativni metod u najopštijem smislu lokacijskog izbora za postavljanje video-nadzora podrazumeva korišćenje kvalitativnih sadržaja iz službenih izvora (studije, elaborati, analize, informacije, pregledi, preseci) i otvorenih izvora (internet-sajtovi, mediji, publikacije, stručni članci). Odnosi se na aktuelne, karakteristične, specifične ili nove bezbednosne pojave i događaje i na njihove okolnosti, uzroke i povode, težinu posledica, kao i prisustvo dodatnih faktora rizika sa aspekta bezbednosti, kao što bi to bili prostori na kojima se održavaju javni skupovi, blizi- 
na škola, sportskih objekata i terena, veća gustina saobraćaja, pojačana frekvencija prolaznika, putnika i protoka roba, kritična infrastruktura itd. I ovaj metod ima ograničenja, koja se ogledaju u otežanoj dostupnosti službenih izvora, nedostatku ili nepotpunosti informacija, složenom postupku uvezivanja većeg broja kvalitativnih izvora itd.

Jedna od veoma korisnih metoda jeste obavljanje neposrednog razgovora sa pripadnicima operativnog sastava policije, i to: kriminalističke policije, policije opšte nadležnosti, a posebno interventnih jedinica policije i saobraćajne policije. Time se dolazi do značajnih zapažanja iz prakse, zasnovanih na iskustvu pripadnika policije o vrlo konkretnim faktorima koji pogoduju kriminalnoj aktivnosti na određenom lokalitetu i, što je veoma bitno, potencijalnim opasnostima koje mogu dovesti do ugrožavanja bezbednosti građana i imovine. Značajan je i kontakt sa pripadnicima Sektora za vanredne situacije u pogledu dobijanja informacija o aktuelnim opasnostima i rizicima u oblasti zaštite i spasavanja.

U izboru lokacija za postavljanje video-nadzora neizostavno je korišćenje savremenih informatičkih sistema, kao što je to geografski informacioni sistem (GIS). Ovaj sistem predstavlja način za vizuelno predstavljanje, analizu i upravljanje geoprostornim podacima, između ostalog, i za potrebe kreiranja bezbednosti u urbanim područjima. Daje elektronski pregled fizičke lokacije i čini osnov za analizu uticaja koje šire okruženje vrši na potencijalnu lokaciju ili uticaja koji mogu proizvesti određene promene na toj lokaciji.

Mapiranje - odnosno vizuelno predstavljanje kroz ukrštanje statističkih podataka, a u određenoj meri i kvalitativnih sadržaja, uz pomoć GIS-a - jedna je od korisnih geometoda prilikom izbora lokacije video-nadzora, kojom se stiče vizeulna predstava o bezbednosnim problemima same lokacije i njenog šireg okruženja.

Dobijanje relevantnih rezultata primenom navedenih metoda u praksi može biti dovedeno u pitanje iz brojnih razloga. Neki od njih su inkompatibilnost programskih sistema koji se koriste u primeni statističke i kvantitativne metode, tehnička ograničenja prilikom povezivanja podataka, nedostatak informacije o raspoloživosti svih kvalitativnih izvora potrebnih u datoj situaciji, različite elektronske i druge forme u kojima se nalaze informacije i podaci itd. Kompletan proces podrazumeva adekvatnu òbučenost za primenu ovih metoda, što u suprotnom, takođe, dovodi u pitanje kvalitet dobijenih rezultata.

Finalno određivanje lokacija podrazumeva neposredno opažanje lokacijskog mesta kako bi se identifikovali svi oni prostorni elementi od značaja za postavljanje i rad video-nadzora. Neposrednim opažanjem je neophodno verifikovati informacije dobijene primenom navedenih metoda i utvrditi postojanje novih činjenica. Takođe, neposrednim opažanjem je potrebno iznaći eventualne prepreke koje mogu ometati rad sistema za video-nadzor. To se prvenstveno odnosi na fizičke prepreke, kao što su zatečeni objekti visoke spratnosti, objekti u izgradnji i drveće, koji mogu da zaklanjaju vidokrug, kao i na faktore koji mogu da utiču na kvalitet snimka (izloženost jakoj ili slaboj svetlosti) ili na opasnost od fizičkog uništavanja ili oštećenja uređaja za video-nadzor (postavljanje u mračnim ili izolovanim delovima). 
Lokacija za postavljanje video-nadzora označava prostor koji po svojim bezbednosnim karakteristikama iskazuje potrebu za stavljanjem pod nadzor radi suzbijanja stvarnih i sprečavanja potencijalnih bezbednosnih rizika, opasnosti i pretnji. Brojnost ovakvih lokacija, naravno, zavisi od veličine samog urbanog prostora. Veliki gradski centri iskazuju veće potrebe. To mogu biti prostori i objekti u kojima se odvijaju događaji sa velikim brojem učesnika: sportska takmičenja, uobičajena okupljanja, poslovni događaji, turističke, kulturne i verske manifestacije; otvoreni prostori, kao što su trgovi, pešačke ulice, stajališta javnog gradskog prevoza, rakrsnice, javna imovina, komunikacije sa većom frekvencijom saobraćaja, putnika i roba; poluotvoreni objekti: međugradske i međunarodne autobuske, kao i železničke stanice, podzemni prolazi, luke i pristaništa; zatvoreni prostori i objekti: tržni centri, muzeji, galerije, banke, zgrade državnih organa, komercijalni i poslovni centri, zgrade državnih organa, javnih preduzeća, inostrana predstavništva i kompanije, turistički objekti, aerodromi itd.

Svaki od ovih krajnje raznovrsnih objekata može biti predmet pojedinačnih ili istovremeno više različitih oblika ugrožavanja bezbednosti, što zadatak izbora lokacija za postavljanje video-nadzora čini složenim. Dijapazon ugrožavanja bezbednosti je širok, počev od pojedinačnih ili serija imovinskih delikata (džepne krađe, teške krađe, krađe vozila, krađa javne imovine, oštećenje i uništavanje imovine itd.), krivična dela sa elementom nasilja (ubistva, teška ubistva i teške telesne povrede, naročito kao posledica obračuna vatrenim oružjem i tuča, razbojništva, razbojničke krađe, silovanja itd.), preko težih prekršaja, krivičnih dela iz oblasti bezbednosti javnog saobraćaja do opasnosti od izvođenja terorističkih akcija.

Pre pokretanja procesa izbora lokacija za postavljanje video-nadzora moraju se imati u vidu i druge važne činjenice. Naime, postupak izbora lokacije treba da prati jasna vizija rezultata koji se žele postići video-nadzorom. To je bitno, pored ostalog, i zbog ograničenosti tehničkih resursa (brojnost kamera, instalaciona ograničenja) i visine finansijskih ulaganja u sisteme video-nadzora. Ta dva faktora neretko primoravaju na sužavanje izbora na bezbednosno najurgentnije lokacije, što, opet, može da znači više kriterijuma (masovnost bezbednosnih događaja, učestalost teških posledica, učestalost bezbednosnih događaja koji trenutno nisu doveli ali mogu dovesti i do težih posledica ili prete da se prostorno prošire, operativno-obaveštajna saznanja policije i službi bezbednosti itd).

Primena sistema video-nadzora pretpostavlja ulogu odvraćanja, što može uticati na premeštanje kriminalnih aktivnosti. To ukazuje na potrebu permanentne analize stanja, tendencija i karakteristika kriminala i drugih bezbednosnih događaja na područjima pod video-nadzorom i područjima koja nisu pod ovom vrstom kontrole, kako bi se pravovremeno identifikovala nova, žarišta “i u skladu sa tim potrebe za novim lokacijama.

Još jedna činjenica važna za izbor lokacije, naročito kada je reč o ,pametnim“ sistemima video-nadzora i video-analitičkim alatima, jeste njihov visok značaj u obavljanju policijskih poslova, koji se, između ostalog, ogleda u sledećem:

- omogućava pravovremenu reakciju na sve vidove bezbednosnog ugrožavanja;

- uvećava istražne kapacitete; 
- doprinosi rasvetljavanju krivičnih dela;

- pojačava preventivne potencijale u borbi protiv terorizma;

- uvećava policijsko-analitičke kapacitete;

- omogućava kvalitetnije planiranje budućih bezbednosnih mera;

- daje informacije o novim pojavnim oblicima bezbednosnih događaja;

- omogućava bolju operativnu koordinaciju;

- omogućava prognozu bezbednosnih opasnosti, pretnji i rizika.

\section{Zaključak}

Neosporno je da sistemi video-nadzora predstavljaju oruđe u borbi protiv destruktivnih oblika ponašanja, a to je još jedan od načina na koji, u ovom trenutku, savremeno društvo reaguje u pravcu unapređenja sopstvene bezbednosti. Video-nadzor spada u red savremenih proaktivnih tehnologija koje paraleleno sa njihovim rapidnim razvojem daju sve veće mogućnosti u kreiranju i oblikovanju bezbednosti u urbanim sredinama i u unapređenju policijske prakse.

Kada je reč o primeni sistema video-nadzora, a naročito novih, zasnovanih na naprednim IT tehnologijama, neophodno je ovladati praksom potpunog i najpogodnijeg iskorišćavanja njihovih raspoloživih mogućnosti, a prvi i temeljni uslov za to čini izbor lokacija za njihovo postavljanje, koji se upravo zbog toga mora odvijati na bazi stručnosti.

$\mathrm{S}$ druge strane, mora se imati u vidu i to da na korišćenje video-nadzora u cilju unapređenja i razvoja urbane bezbednosti utiču i drugi važni aspekti, kao što su opasnosti od zloupotrebe, neusaglašen odnos javnosti prema ovoj temi i rešavanje brojnih otvorenih pitanja u pogledu zaštite privatnosti i pravnog uređenja ove materije. Ova pitanja su još složenija ako imamo u vidu da iziskuju odgovor adekvatan mogućnostima savremenih video-nadzora koje su u neprestanom razvoju.

\section{Literatura}

1. Gligorijević, M., Čisar, P., Osnovi telekomunikacija, udžbenik, Kriminalističko-policijska akademija, Beograd, 2017.

2. Gligorijević, M., Maksimović, A., Vučković, J.: Forenzički i pravni aspekti upotrebe sistema video nadzora u dokazivanju krivičnih dela i prekršaja, Međunarodni naučni skup „Dani Arčibalda Rajsa“, Zbornik radova, Kriminalističko-policijska akademija, Beograd, 2016.

3. Kovačević Lepojević, Marina, i Žunić Pavlović, Vesna, Fakultet za specijalnu edukaciju i rehabilitaciju Univerziteta u Beogradu, „Primena video nadzora u kontroli kriminala“, Specijalna edukacija i rehabilitacija, broj 2, 2012.

4. Danilović Hristić, Nataša, Bezbednost urbanih prostora, Orion art, Beograd, 2013.

5. Nikolić, V., Đikanović, P., Jokić, N., Sistem video nadzora za automatsko prepoznavanje registarskih tablica motornih vozila, Infofest, Budva, 2013. 


\title{
ANALYTICAL APROACH IN SELECTING THE LOCATION FOR INSTALLING VIDEO SURVEILLANCE SYSTEM AND ANPR SYSTEM IN URBAN AREAS
}

\begin{abstract}
Summary
Information and communication technologies and state-of-the-art systems are an indispensable segment of social life. Without such modern devices, a modern man may find himself in communicative isolation, and his inability to match the challenges in a ruthless and dynamic environment with adequate response might jeopardize his survival. In such circumstances, the use of information and communication systems and technologies is of crucial importance.

Development of high technologies has brought revolutionary changes in all fields of social life. There is almost no area where those technologies are not applied - engineering, commercial and industrial processes, state administrations, science, education, medicine, national defence and security, etc. As for the field of security, high technologies are crucial, especially as mechanisms of security protection - independently or to support other forms of protection. Some of the applications are video surveillance systems that represent the most advanced model for controlling and monitoring certain security events and incidents and enable timely responses to certain types of threats to physical safety and property of citizens, which is of particular importance. At the same time, they are a good basis for gaining experience relevant to the planning of security measures regarding specific security events and phenomena in future. If we add the fact that video surveillance systems have a strong preventive potential, it is clear that they are one of the most reliable modern means of security protection.

Examples of application are numerous, but this paper analyses the latest generation of video surveillance systems, the so-called "intelligent video surveillance", with special emphasis on the proper approach, the analytical aspect of the planning methodology, location selection and installing these systems in urban areas. Also, the paper points out the very important role and the importance of intelligent video surveillance system in everyday life and work of people in urban areas.
\end{abstract}

From a security and protection point of view, urban areas are considered to be very difficult and complex. Application of video surveillance system, including the advanced video analytics of recorded material, primarily involves the correct selection of locations, as well as other conditions fulfilled, such as the use of certain analytical, statistical and geospatial methods.

The paper discusses three methods and provides an overview of their options. Analytical method is analysed from a different points of view: the use of the existing security information which indicates the urban "focal" point, the manner of collecting and processing information, but also the need to find a model for further collection and classification, which will provide a good basis for eventual revision of selected locations in line with the trends and developments 
of the security situation. The attention is drawn to one of the most important analytical methods, such as direct conversation with the operational police officers in order to obtain the high-quality information necessary for the selection of location.

The paper also points out the possibility of statistical methods which can help to extract and cross all kinds of information - the frequency of people and vehicles, the type, scope and frequency of security phenomena and events, such as serious crimes, offenses and traffic accidents along with their consequences in certain urban areas, etc.

Using modern information tools in selecting the location is characterized by the use of Geographic Information System (GIS) as a kind of method for analysing geospatial data of tactical and strategic security importance emphasized in this paper. Geographical information in terms of the analysis of the situation and trends of crime enables us to consider all dominant conditions in the particular location and helps to spot differences between similar locations. GIS gives answers about locations, influences of a wider environment, effects that may lead to changes on certain location, and the fastest, shortest or most urgent paths. Geographic Information System (GIS) is one of the most powerful tools for managing spatial data that best helps to understand the nature of the space, and provides great opportunities, which have not been sufficiently exploited or introduced to the extent necessary in practice and policing.

The paper also points out not only the importance of GIS but the need for mapping crimes, misdemeanours, traffic accidents including fires and explosions, as well as other forms of threats, especially those that endanger the locations with a high concentration of people (frequency places, the usual gathering places, public meetings, business events, tourist, cultural, religious events, etc.). Mapping represents a significant source of data for the evaluation of certain location to be included in video surveillance systems.

The paper presents a number of problems that can affect the quality in the application of analytical, statistical and geospatial methods in the context of location selection, regarding the lack of information and data, insufficient training, incompatibility of necessary software system, technical limitations in the use of data, etc.

We must mention the importance of intelligent video surveillance systems in the context of revealing the specific criminal offenses, which has been proved in practice, as well as revealing security threats. Utility value of such intelligent video surveillance systems is in providing bigger and better ability to collect information on new forms of threats and the ways that threats take place. It should be also noted that gathering information in the future could be used for the implementation and development of predictive-analytical methods, which means predicting certain risks and security risks in specific locations.

Advanced video analytics, which is a part of an integrated intelligent video surveillance system, enables the analysis of video material on several different grounds, such as:

- analysis of the human behaviour in the certain area (detecting events in the realtime, for example: leaving the object/location, an increased number of people in an area, entry into the defined area, longer staying in certain area, wrong directions, frequency of people, etc.); 
- intelligent video searches done according to different criteria: space, time, events on the location, object and object type (truck, man, object), the colour of the object, the zone on the scene, detection of direction...;

- video synopsis, as a summary display of the video material obtained by defined detection method;

- recognition of license plates of motor vehicles in real time and searching recorded material;

- automatic face recognition.

Determination of the trajectory of persons and vehicles through integration with GIS platform is an optimal device for surmounting the above-mentioned problems. Once again, we should highlight the importance of the proper selection of location for the installation of the video surveillance system - a system that certainly represents the future of reliable security to protect citizens and property.

Keywords: information and communication technology, intelligent video surveillance system 